\title{
Small and Medium Scale Enterprises as A Survival Strategy for Employment Generation in Nigeria
}

\author{
Dr. Aremu, Mukaila Ayanda (Corresponding author) \\ Department of Business Administration, Faculty of Business and Social Sciences \\ University of Ilorin, Ilorin, Kwara State, Nigeria \\ Tel: 234-803-671-8531_E-mail: aremuilala@unilorin.edu.ng \\ $\&$ \\ Dr. (Mrs.) Adeyemi, Sidikat Laraba \\ Department of Business Administration, Faculty of Business and Social Sciences \\ University of Ilorin, P. M. B. 1515 Ilorin, Kwara State, Nigeria \\ Tel: 234-805-445-1111 E-mail: sidiadeyemi@yahoo.com
}

\begin{abstract}
Small and medium enterprises have been considered as the engine of economic growth and for promoting equitable development. The major advantage of the sector is its employment potential at low capital cost. The labour intensity of the SME sector is much higher than that of the large enterprises. The role of small and medium enterprises in the economic and social development of the country is well established. The sector is a nursery of entrepreneurship, often driven by individual creativity and innovation.

The paper concludes that besides the growth potential of the sector and its critical role in the manufacturing and value chains. There wide spread in Nigeria and the multiplier effects they have on the rest of the economy enable them to be the engine of economic progress. It was also noted that the SME sector is the main driving force behind job creation, poverty reduction, wealth creation, income distribution and reduction in income disparities. Most of the government interventions failed to create a much needed transformation due to poor coordination and monitoring and policy inconsistencies.

SME sector also formed the vanguard of the modern enterprise sector and presents the propelling force of economic modernization and growth in Nigeria. They are important sector that need to be adequately factored into policy making and programme implementation in Nigeria.
\end{abstract}

Keywords: Small and Medium scale, Unemployment, Capacity building and Strategy

\section{Introduction}

The relative importance of small and medium scale enterprise in advanced and developing countries has led and would continue to lead to a reconsideration of the role of Small and Medium Scale Enterprises in the economy of nations. The development of many countries is often measured by such indices as the level of industrialization, modernization, urbanization, gainful and meaningful employment for all those who are able and willing to work, income per capital, equitable distribution of income, and the welfare and quality of life enjoyed by the citizenry. There is no doubt that small scale enterprises exist in most economic environment. The historical background of small and medium scale enterprises in Nigeria can be traced back to 1946 when the essential paper No. 24 of 1945 on "A Ten year plan of development and welfare of Nigeria 1946 was presented. Small and Medium Scale Enterprise is an all time necessity. It was there at the beginning; it was gained prominence today and will increase its importance tomorrow. This is simply dictated by the developmental needs of the Nigeria society.

In recognition of the depth and breath of the consequences of small-scale enterprises in alleviating poverty and national development, there has been a deep-self interest in recent years for development of Nigerians small-scale enterprises particularly since the adoption of the economic reform in 1986. The small and medium scale industry is seen as a key to Nigeria's growth and alleviation of poverty and unemployment in the country. Therefore, promotion of such enterprises in developing economies like Nigeria is of paramount importance since it brings about a great distribution of income and wealth, economic self-dependence, entrepreneurial development employment and a host of other positive, economic uplifting factors (Aremu 2004). Moreover, in a country like Nigeria with an adverse Balance of Payment situation, the growing contribution of the Small Scale Industries sector in Nigeria's export portfolio goes a long way in generating foreign exchange and smoothening out the adverse Balance of payment situation. Aremu (2004) posited that Small Scale enterprises play an important role in the economics of any country in accordance with their relative levels of development. He 
further emphasized that Poverty is a worldwide phenomenon and its incidence in Nigeria had been high and on the increase since 1980. This position is in line with (Adeyemi and Badmus 2001 and Schmitz 1982), they also argued that adequate financing of small and medium scale enterprises will reduce the unemployment level in Nigeria.

There is a general believes that desire employment generation in this country can be achieved through development of small and medium scale enterprises (Awosika 1997, Schmitz 1995). Gunu (2004) and Aremu (2010) posited that Small Scale Enterprises provide income, savings, and employment generation. They are seen as veritable engines for the development of entrepreneurial capabilities and indigenous technology which will generate employment in the country. Small and medium scale industries constitute the basis for industry and natural economy in many countries. It has been estimated that SME's employ $22 \%$ of the adult population in developing countries (Daniel 1994 and Fisseha 1991). Small and medium scale enterprises can be regarded as one of the important element of a country development and this play a crucial role in the economy of this nation. Small and medium scale enterprises speed up the rate of social economic development of many countries, particularly developing countries. They served as system for attainment of national objective in terms of employment generation at low investment cost and also the development of entrepreneurial capabilities and indigenous technology. It also reduce the flow of people from rural area to urban area, henceforth, it can be easily established by the relatively less skilled labour force of a developing country, Small and Medium Scale Enterprises contribute substantially to the gross domestic product, export earning, and development opportunities of the countries. After the attainment of independence much emphasis has been laid on growth of small and medium scale industries as means of reduce the incidence of poverty and employment in the country.

At the early stages of industrialization, Japan economy was characterized by traditional industries and large number of small firms who as of that time draw their strength not from an abundant supply of capital, but from their vast supply of labour. So in Japan "during the interwar years (1919 - 1938) and after government policies accorded and continue to accord due priority to country small and medium scale enterprise (Mosk, 2010).

Various studies conducted indicated about 50 per cent of small and medium scale enterprises surveyed did not receive external finance while 77 percent indicated lacked of access to financial resources. The secret behind the success of a self-reliant strategy in any economy does not lie solely in any particular socio-political or socio-economic philosophy, but so much on people's attitude to small enterprises. The objective of this paper is to examine relevance of small and medium scale enterprises as a means of generating employment and reduce poverty in the country.

\section{Literature Review}

The findings have shown that most SMEs particularly in Nigeria die within their first five years of existence. It was also revealed that smaller percentage goes into extinction between the sixth and tenth year while only about five to ten percent of young companies survive, thrive and grow to maturity. Many factors have been identified as likely contributing factors to the premature death. Key among this include insufficient capital, lack of focus, inadequate market research, over-concentration on one or two markets for finished products, lack of succession plan, inexperience, lack of proper book keeping, irregular power supply, infrastructural inadequacies (water, roads etc), lack of proper records or lack of any records at all, inability to separate business and family or personal finances, lack of business strategy, inability to distinguish between revenue and profit, inability to procure the right plant and machinery, inability to engage or employ the right caliber staff, cut-throat competition (Basil 2005).

Countries do not use the same definition for classifying their SME sector. Nor does a universal definition appear to be necessary. The definitions in use depend on the purposes those definitions are required to serve and the policies which govern the SME sector. However, the three parameters generally applied by most countries, singly or in combination are: capital investment on plant and machinery; number of workers employed; and volume of production or turnover of business.

Despite that there are no universal quantitative norms, the SMEs as a class are clearly distinguishable in many countries, be it developed or developing. The factors that set them apart are essentially quantitative or comparative.

On the quantitative side are their internal management structures, decision - making process, financial practice, trading styles, attendance risk factor, etc. It has been observed that most SMEs are one person shows or are run by two or three individuals, usually relatives, friends or business partners, who take most of the decisions. There is no serious distinction between private and business assets, and subjective and personal factors play a large role in decision - making. The personal stakes SME entrepreneur have in their business are much higher than those 
of the corporate executives in their businesses are much higher than those of the corporate executives in their companies. This enhances the attendance risks and commits entrepreneurs even more strongly to the success of their ventures.

The findings indicate that high levels of technical inefficiency, which reduce their potential output levels significantly, characterize the Nigeria SMEs. There is therefore strong need to assist SMEs to improve their technical efficiency through adequate supply of inputs, markets, and credit facilities, and undertaking extensive infrastructural development and training could be important measures.

The comparative factors have to do with the way SMEs are situated vis-à-vis large enterprises in the corporate sector. They are small and medium sized in comparison with the large corporate entities with which they share a given economic space. SMEs therefore come in varying sizes and SMEs in one country may well be larger than 'big' companies in another. The interesting feature is that, not withstanding their absolute sizes, the problem confronting SMEs appears to be similar in most countries whether developing or developed. However, the levels of obstacles vary from country to country, industry to industry and depend on firms' characteristics. The following are some of the obstacles that are being faced by Nigeria SMEs:

i. Inadequate access to credit particularly on moderate terms. This has negatively affected the growth of SMEs and their development in Nigeria.

ii. Decision-making skills, sound management and accounting practices are very low among the Nigeria SMEs operators.

iii. Commercial banks find it uneasy to assess risk premiums properly, this lead to differences in the perceived versus real risk profiles of SMEs in Nigeria.

It is these features, which set them apart as a distinctive group, and it is these factors, and not the quantitative definition, which are common and have universal applicability.

Within the Nigeria context, the best way to capture the definition as posited by NESG (2002) is based on the nature of business and magnitude. For instance, roadside artisans, petty - traders, pure /bottled water producers, bakers, local fabricators (regarded as micro enterprises) should constitute part of SMEs.

There is a considerable danger that an overemphasis on entrepreneurship within management literature may preclude examination of other factors leading to growth in SMEs. Clearly entrepreneurial drives need examination and the work of Chell and Adam (1993) brings us up to date with current thinking (see also Day and Reynolds, 1995). But increasingly attention is being focused on growth. In this respect the Bangermann Report (Bangermann, 1994) is worthy of reference. Some theorists such as Churchill and Lewis, (1983) identify growth stage models; those attempt to link growth with particular stages of development. However more examination is needed of SME's capability to adapt, deploy skills and focus assets and of how such procedures lead to ultimate success. Clearly as firms and particularly SMES grow they face threats and opportunities and it is legitimate that management researchers should seek to examine the influences. These internal factors are probed and conclusions reached mainly with regard to the firm's value chain.

In 1990 budget, the Federal Government of Nigeria defined small scale enterprises for the purpose of commercial loan as those enterprises with annual turnover not exceeding $\$ 500,000$ and for merchant loan as those for the purpose of commercial loan as those enterprises with capital investment not exceeding million (excluding cost of land or a maximum of $\$ 5$ million).

According to Umar (1997) the concept of the small size firm is a relative one and it depends mainly on both the geographical location and the nature of economy activity being performed. According to LeGrand et al (1992) and Schubert (1994) they perceive poverty as either absolute or relative or both. Absolute poverty being that which could be applied at all time in all societies, while relative poverty relates to the living standards of the poor to the standards that prevail elsewhere in the society in which they live. Englama et al (1977) also defined poverty in both absolute and relative terms as a state where an individual is not able to cater adequately for his/her basic needs of food, clothing and shelter. Lacks gainful employment, skills, assets and economic infrastructures such as education, health, potable water, and sanitation, and as a result has limited chance of advancing his/her welfare to the limit of his/her capabilities.

World development Report (1990) used an upper poverty line US \$ 370 income per capital as a cut off for absolute poverty. People whose consumption level falls below that level are considered poor and those below US $\$ 275$ as very poor. Obadan (1997) sees poverty as a situation of low income or low consumption. Some researchers also defined it as inability to meet basic material needs encompassing food, water, clothing, shelter, 
education, health as well as basic non-material needs including participation, identity, dignity, etc (Streeten 1997, Blackwood and Lynch 1979).

As a result of flexibility nature of small -scale enterprises, they are able to withstand adverse economic role since they are more of labour intensive. Therefore, they have lower capital costs that are associated with job creating (Anheier and Seibel, 1987; Liedholm and Mead, 1987; Schmitz, 1995)

It is essential for the Nigerian government to realize the important of small-scale enterprises and formulate appropriate comprehensive policies to encourage, support and fund the establishment of small-scale enterprises. This is because development of small-scale enterprises is sine qua non for employment generation, encouragement for the use of local raw materials, employment generation and alleviation of poverty.

\section{Small and Medium Scale SMEs Capacity Building in Nigeria}

In recognition of SMEs substantial contribution to the country's economy, the strategies and initiatives to promote SME development features prominently in most of the government's economic development plans over with a view to nurturing further growth in the sector. Over the last decade, a clear path for accelerating the development of SMEs has been charted through the establishment of agencies such as DFRRI, NDE, NAPEP, etc. although the challenges before this establishment are daunting (Ogwuma, 1995).

The state led models of industrialization followed immediately after Nigerian independence in 1960 and those of 1970s and 1980s was a major factor constraining the growth of SMEs. There are many ways in which industrialization discriminated against SMEs during the time.

First, trade was regulated in a way that followed large firms to obtain import licenses, official exchange rates for imports, and tariff rebates more easily than small firms. The anti-export bias induced by import substitution strategies also discriminated against intensive SMEs. Moreover, small firms were denied access to most investment incentives because of high rent-seeking costs.

Secondly, financial sector interventions also discriminated against SMEs. Selective credit controls in conjunction with controlled interest rates prevented banks from compensation for the higher cost small loans by charging more. As a result, small clients were allocated limited credit, allowing large firms to grow at the expense of small firms.

Thirdly, the problems of dealing with government regulations and tax authorities weighted more heavily on smaller firms in the shape of higher compliance costs, i.e. the fixed costs of complying with import/export and tax regulations, labour market regulations, and licensing and price control.

Fourth, Nigeria's underdeveloped physical and social infrastructures create a binding constraint to SMEs growth. SMEs rely heavily on inefficiently provided state infrastructures such as electricity and water and cannot afford the cost of developing any alternatives. Similarly, inadequate investment in human capital hampers SME growth because of the scarcity of skilled workers, managers and entrepreneurs (Tendler and Amorim 1996).

In more challenging environment SMEs are aware of the need to become more resilient and competitive in the face of economic changes. The continuous changes that affect the business environment, due to the globalization process and the technology innovations, force Small and Medium Scale Enterprises and other organizations in Nigeria to constantly look for new competitive advantages in order to maintain and improve their market position (Aremu 2004). Towards this end, the government efforts should be directed to strengthening SMEs and thus encouraging domestic investment and promoting economic growth.

\section{Small and Medium Scale SMEs Strategy for Sustainability}

Sustainable development is recognized as an essential requirement for achieving economic goals without degrading the environment, major problems arise in implementing the concept of sustainability. At the most basic level, researchers dealing with sustainable development have suggested that the achievement of sustainability requires ecologically sustainable political and economic systems, organizations, and individuals (Starik and Rands 1995; Costanza and Daly 1992; Gallup International Institute 1992). Specifically, governments, consumers, and enterprises contribute and play crucial roles in reaching sustainable development. As a result, if goals of sustainability are to be achieved, small and medium-sized enterprises must be reformed to minimize their negative ecological and social impacts (Gladwin, 1992).

Generally, SMEs will have to assist and facilitate growth, multiply and replicate into sufficient mass across industries and sectors. The SME sector is considered to be the backbone of the modern day economy. The importance of this segment is undisputed. However, the yawning gap between the needs, demands and policy response in this unorganized sector has always dampened the sector's prospects. The recent economic turbulence 
has only added to the sector's problems. Hence, it becomes imperative for us to ensure that SME sector, which is facing one of the toughest times in the industrial history, should be strongly supported by the relevant stakeholders - government, financial institutions, associations, etc. This is to enable the sector to play its sustainability roles in the economy.

SMEs contribution towards sustainable development is small, taken together SMEs have a very large impact on the development quality of a specific geographic area. The more presence of SMEs in the economy of a particular area, the more important is the SMEs role for achieving sustainability (Welford and Gouldson, 1993).

In comparison with large companies, SMEs show particular benefits for a geographic area interested in achieving a sustainable development, which can be grouped in the following categories: economic, socio-cultural, environmental, and collaboration contributions. Major economic contributions to sustainability come from the fact that residents and indigenous are more probably to own and run SMEs than larger companies, which frequently are multinational companies.

Specifically, in the SMEs, the management process is characterised by the highly personalised preferences, prejudices, and attitudes of the firms' entrepreneur, owner and/or owner-manager (Jennings and Beaver, 1995). As a result, SMEs allow residents and indigenous to participate in the economic development and, consequently, to obtain the economic benefits generated by the community (Howard and Hine, 1995).

Furthermore, SMEs which are owned and run by residents who are expected to reinvest their benefits in the community itself, while large companies usually act internationally. Finally, SMEs draw out capital that would otherwise remain underexploited by the economy, and help develop new markets by improving forward and backward linkages between economically, socially, and geographically diverse sectors of the economy (Howard and Hine, 1995). These SMEs potential economic contributions to sustainability might be balanced against overall economic efficiency of SMEs in comparison with larger companies; meaning that SMEs operating in a particular community must be internationally competitive in order to make significant contributions to sustainability (Diego and Juan 1998).

\section{Conclusion and Policy Recommendation}

It is becoming increasingly apparent to government and policy makers that the role of small and medium scale enterprises is very important to the development and growth of any given economy. Small and medium scale enterprises will ensure efficient use of resources, employment creation, mobilisation of domestic saving and investment.

Finance is the most important and cogent key of any enterprises. Small and medium scale enterprises must be financially supported so that they can take off and expand and be able to meet the needs of the Nigerians. Shortage of indigenous entrepreneurs has been identified as a major impediment to economic development.

It is also recommended that there is need for supporting and strengthening SMEs' productive capacities and market competitiveness of Small and Medium Scale Enterprises in the country.

This therefore calls for the need for establishment of small-scale enterprises as a way of developing and providing a training ground for indigenous entrepreneur. The rural urban drift is due to lack of job opportunities in the rural area. Thus, small-scale enterprises will help to reduce this drift particularly when they are sited in rural areas.

Non capital-intensive nature of small-scale industries is another important significance of small-scale enterprises. They are usually started with small saving which made them affordable to go into. The meager capital requirement of small-scale enterprises makes them to promote an even distribution of income in the economy. This is because if there is adequate financial support, more unemployed Nigerians will engage in small scale enterprises thereby gain their means of living easily than looking for unavailable while collar job. There is need for establishment of Small-scale enterprises since they ensure community stability since small-scale enterprises do less harm to the physical environment than large enterprises. They promote agro-industries, improve rural welfare and generally reduce unemployment and poverty in the country.

In advanced economies, the SME sector is acclaimed as the engine of economic growth and development. However, against international best practices Nigeria is rated poorly. Extensive efforts in terms of strategic programmes, policy and practice will be required to elevate Nigeria to a leading position. Though Nigeria lacks adequate census on relevant economic indices, it is estimated that Small and Medium Enterprises in Nigeria currently account for over $75 \%$ of employment in the country (SMEDAN 2006). This relatively high percentage is however a paradox as $60 \%$ of Nigerians still lives below the poverty level (UNDP, 2005). When 60 percent 
living below the poverty line are taken into account, the share of those gainfully employed in the SME sector is more likely to be in the region of $10 \%$ as recorded by US Industry Small Business Administration (SBA).

Finally, government as a matter of urgency, should prioritise the SME sector giving it devoted practical and visible attention with a view to make it virile, vibrant, focused and productive. The era of 'lip service' attention to the sector should be done away with. The employment creation cannot be developed without a vibrant SME subsector, and so government should do all within its arsenal to reverse the situation.

\section{References}

Adeyemi, S. L. and Badmus, A. L. (2001). An Empirical Study of Small Scale Financing in Nigeria, Journal of Unilorin Business School, 1 (1).

Anheier, H. K and Seibel, H. D. (1987). Small Scale Industries and Economic Development in Ghana: Business and Strategies in Informal sector Economics, Verlag Breitenbech, Saarbruckh, Germany.

Aremu, M. A. (2004). Small Scale Enterprises: Panacea to Poverty Problem in Nigeria, Journal of Enterprises Development, International Research and Development Institute, Uyo, Akwa Ibom, Nigeria, I(1): 1 - 8 .

Aremu, M. A. (2006). Adoption of Direct Marketing as Strategic Marketing Approach in Nigerian Banking System. ABU Journal of Marketing Management, A Publication of Department of Business Administration, Ahmadu Bello University, Zaria, Nigeria, 1(2): 94 - 110.

Aremu, M. A. (2010). Small and Medium Scale Enterprises As A Means of Employment Generation and Capacity Building In Nigeria, A Paper Presented at the International Conference on Management and Enterprise Development on "Intellectuals and New Strategies for Sustainability Development of the Third World" Held at Conference Center, University of Ibadan, Ibadan, Nigeria, October $5^{\text {th }}-8^{\text {th }}$.

Awosika, B. O. (1997). Evolving a National Framework for the Emergency of a Strong and Virile Small and Medium Scale Industry Sub-Sector in Nigeria. A Seminar Paper Presented at MAN House, November $5^{\text {th }}$ p.3.

Basil, A. N. O. (2005). Small and Medium Enterprises (SMES) in Nigeria: Problems and Prospects, Ph.D. Thesis, St. Clements University.

Bangemann, M. (1994), Europe and the global information society, Recommendations to die European Council, EU Brussels.

Blackwood, D. L. and Lynch, R. G. (1994). The Measurement of Inequality and Poverty: A Policy Maker's Guide to the Literature, World Development, 22(14): 568 - 570.

Chell, E. and Adam, A. (1993). Transitional issues in moving from an entrepreneurial to a professionally managed firm, Paper Given at the 16th National Small Firms Policy and Research Conference, Nottingham

Central Bank of Nigeria. (CBN). Annual Report 2006

Churchill, N.C. and Lewis, V.L. (1983). The five stages of small business growth, Harvard Business Review, $30-50$.

Costanza, R. and Daly, H. E. (1992). A Natural Capital and Sustainable Development. Conservation Biology. 6: $37-46$.

Daniels, L and Ngwira, A. (1993). Results of a Nationwide Survey on Micro, Small and Medium Enterprises in Malawi, GEMINI Technical Report No 53 PACT Publications, New York.

Day, J. and Reynolds, P. (1995). The importance of correctly defining entrepreneurship when studying SME's, Paper Presented at the 18th ISBA National Conference, Paisley.

Diego, M. and Juan, M. G. (1998). Sustainability as a Major Source of Competitive Advantage for Small and Medium Sized Enterprises, 7th International Conference of the Greening of Industry Network, November 15-18, Rome, Italy.

Englam, A. and Bamidele, A. (1997). Measurement Issues in Poverty. In Poverty Alleviation in Nigeria, a selected paper for 1997 Annual Conference of the Nigeria Economic Society, NES, Pp. 141-156.

Fissaeha, Y. (1991). Small Scale Enterprises in Lesotho: Summary of a Countrywide Survey, Gemini Technical Report, No 14 Washington D.C, Development Alternatives Inc.

Gallup International Institute. (1992). Survey of Environmental Attitudes. Gallup International Institute. Princeton NJ. 
Gladwin, T. N., Kennelly, J. J. and Krause, T. S. (1995). A Shifting paradigms for Sustainable Development: Implications for Management Theory and Research. Academy of Management Review. 20 (14): 874 - 907.

Gunu, U. (2004). Small Scale Enterprises in Nigeria: Their Start Up, Characteristics, Sources of Finance and Importance, Ilorin Journal of Business and Social Sciences, 9 (1 \& 2): 36 - 43.

Jennings, P. D. and Beaver, G. (1995). The performance and competitive advantage of small firms: A Management Perspective. International Small Business Journal. 15 (2): 63 - 75.

Howard, D. and Hine, D. (1995). The Population of Organisations Life Cycle (POLC): Implications for small business assistance programs.

Legrand, M. et al. (1992). The Economic of Social Problems, London, Macmillan Press.

Liedholm, C. and Mead, D. (1987). Small Scale Industries in Developing Countries: Empirical Evidence and Policy Implications. International Development paper No9, Department of Agricultural Economic, Michigan State University, East Lansing. MI: USA.

Mosk, C. (2010). Japanese Industrialization and Economic Growth, available online at http://eh.net/encyclopedia/article/mosk.japan.final

Nigerian Economic Summit Group. (2002). A Survey of Micro and Small Enterprises, NESG Digest, Lagos.

National Policy on Micro, Small and medium Enterprises - SMEDAN, UNDP (2006)

Obadan, M. I (1997). Analytical framework for poverty Reduction Issues of Economic Growth Versus other Strategies. in poverty Alleviation in Nigeria (Nigerian Economic Society (NES) Annual Conference Proceedings.

Ogwuma, P. A. (1995). Revitalizing the manufacturing Sector CBN Bullion Vol. 19 no2. April -June P.2.

Schubert, R. (1994). Poverty in Developing Countries: its Definition, extent and Implication. Economic, Vol. 49-56: $17-40$.

Schmitz, H. (1982). Growth Constraints on Small Scale Manufacturing in Developing Countries: A Critical Review, In World Development, 10 (6): 429 - 450.

Schmitz, H. (1995). Collective Efficiency: Growth Path for Small - Scale Industry, Journal of Development Studies, 31 (4): 529 - 566.

Starik, M. and Rands, G. P. (1995). A Weaving an integrated web: Multilevel and Multisystem Perspectives of Ecologically Sustainable Organizations. Academy of Management Review. 20 (14): 908 - 935.

Tendler, J. and Amorim, A. M. (1996). Small Firms and their helpers: Lessons on Demand. World Development. 24 (3): 407-426.

The Global Competitiveness Report 2008 - 2009; (World Economic Forum)

Umar, A. B. (1997). Financing small and Medium Scale industries in Nigeria. A Paper Presented at A day Conference Survival and Development of Small and Medium Scale Industry Sector in Nigeria, Nov. P13.

Welford, R. and Gouldson, A. (1993). Environmental management and business strategy. Pitman Publishing. London.

World Bank (1990). World Development Report 1990 Poverty Oxford University press Oxford.

The Economic Times. (2009). ET India MSME Summit Dossier, Vol 1. 